\title{
Code-switching as appraisal resource in talking about third parties
}

\author{
Nicole Baumgarten (Sønderborg) \& Inke Du Bois (Bremen)
}

\begin{abstract}
This article explores the function of code-switching in talking about absent third parties. The basis for the investigation is a corpus of sociolinguistic individual and group interviews with German immigrants in the US and American immigrants in Germany. In these interviews, the interviewees are asked to recount their migration experiences and their lives before and after migration. For each individual speaker, the interviewer and - in the group interviews - the other participants in the group are, on the one hand, potentially 'sympathetic' fellow migrants. On the other hand, however, they are potentially problematic figures, because talking about absent third parties means that these third parties might share characteristics with the interviewer or the others in the group. Talking about third parties can, thus, be face-threatening for both the interviewer and the interviewees. In the analyses presented in this article, we identify how speakers employ English-to-German code-switching when it comes to verbalizing others - specifically members of home and host cultures - in discourse and how they position themselves and their audience in relation to them.
\end{abstract}

\section{$1 \quad$ Introduction}

This article explores the function of code-switching in talking about absent third parties. The basis for the investigation is a corpus of sociolinguistic individual and group interviews with German immigrants in the US and American immigrants in Germany. In these interviews, the interviewees are asked to recount their migration experiences and their lives before and after migration. For each individual speaker, the interviewer and - in the group interviews - the other participants in the group are, on the one hand, potentially 'sympathetic' fellow migrants. On the other hand, however, they are potentially problematic figures, because talking about absent third parties means that these third parties might share characteristics with the interviewer or the others in the group. Talking about third parties can, thus, be face-threatening for both the interviewer and the interviewees.

In the analyses presented in this article, we identify how speakers employ English-to-German code-switching when it comes to verbalizing others - specifically members of home and host cultures - in discourse and how they position themselves and their audience in relation to them. Drawing on the frameworks of positioning analysis (c.f. Lucius-Hoene/Deppermann 2002, 2004) and appraisal analysis (c.f. Martin/White 2005) we show how code-switching helps to instantiate third parties in discourse, how it functions to convey evaluations of and judgments about the third parties, and how it serves interviewees to construct relations of alliance, opposition and distance between themselves, the interviewer and the third parties. In the following sections, we will first present the database for this study (Section 2). The interview situation will be described in considerable detail, because it is the affordances of this specific communicative encounter and its particular interpersonal constellation that give rise to the code-switches in the service of talking about third parties in the first place. Sections 3 and 4 
introduce the concept of code-switching followed in this study and the type of talk about third parties that occurs in the interview data. Section 5 summarizes the main aspects of positioning analysis and appraisal analysis. Section 6 presents three exemplary analyses of code-switching as an appraisal resource in the data. Section 7 is the conclusion.

\section{Interview data}

Because communication is always a fundamentally interactive undertaking, language use, language choice and interactional behaviour - which encompass phenomena such as switching into another language, talking about absent others, or expressing evaluations - do not occur and can not be interpreted outside a particular communicative context. This is true for both 'naturally occurring' discourse and elicited discourse data, such as research interviews. In a recent article on the qualitative research interview as a "real communicative event", DeFina/Perrino (2011) argue that the sociolinguistic research interview has to be placed in and analyzed in the context of its occurrence in order to fully understand the language practices adopted by both the researcher/interviewer and the informant/interviewee. The authors oppose the idea that it is possible or even desirable to try to reduce the Observer's Paradox (Labov 1972) in research interviews and make participants forget about the fact that they are taking part in an interview event in an attempt to make them display 'natural' communicative behaviour - i. e. behaviour that is not triggered by or grounded in the interview context. DeFina/Perrino (2011) favour a view on interviews as interactional events in their own right, which create the environment for particular, context-bound types of language use and interactional behaviour. Accordingly, the analysis of the functions of codeswitching in talking about third parties must start from a re-contextualizing description of the data in which the code-switching occurs.

The code-switching data come from two sets of sociolinguistic research interviews that were collected for two studies on the construction of cultural identities in migration contexts (Du Bois 2007, 2010a). One set comprises individual interviews with US-American immigrants in Germany. The second set comprises group interviews with German immigrants in the US.

The individual interviews with US-Americans in Germany were carried out in a one-on-one manner in private homes and public places. There were neither overhearers nor bystanders present. The interviews are a mixture of turn-by-turn and discourse unit interviews. The goal of the interview questions was to elicit longer stretches of self-portraying autobiographical talk from the interviewee, e.g. in the form of narratives, descriptions, accounts and self-reflections. The dominant, or 'matrix', language of the interviews is English. Depending on the length of residence in Germany, the US-American immigrants' proficiency in their second language (L2) German at the time of data collection was from intermediate to very advanced and native-like. The interviewer/researcher is German-American with German as her first language (L1). At the time of data collection she had recently re-migrated from the US to Germany - a fact the interviewees knew about. Thus, interviewer and interviewee share a comparable migration experience, they are both English-German bilinguals and have overlapping cultural background knowledge about Germany (in general and with respect to their common area of residence at the time of data collection) and the US to draw upon in interactional meaning making. The interviewer, however, is also a representative of the German majority culture.

The languages used in the group interviews with German immigrants in the US are English and German. Longer stretches of English and German-language talk - both interspersed with code-switches into the other language - follow one another. The interviews took place in the simulated social setting of informal dinner parties in the researcher's private home. The interview questions targeted reflection about the interviewees' status as German immigrants in the 
US and differences between living in the US and in Germany. The interviewer took the role of participant observer, staying in the background as long as the interviewees' talk centred around the questions posed. Both interviewer and interviewees are German, with German as their L1. At the time of data collection all were relative strangers to each other. They shared, however, a comparable length of residence in the US as well as the area of residence, which provided them with comparable regional and local knowledge about the US. In addition, interviewer and interviewees shared the same migration experience and they had access to largely overlapping cultural knowledge about Germany and the US as the basis for conversational inferencing.

The two interview set-ups feature slightly different types of identity constellations between research/interviewer and informant/interviewee. Zimmerman (1998) posits that participants' orientation to their own and their interlocutors' identities or roles is a crucial feature of communicative interaction, because it determines the individuals' language choice and serves as the context in which the interlocutors' interactional behaviour is interpreted. He distinguishes between three types of identities that speakers can assume in interaction and which can become relevant or consequential for the moment-by-moment organization of the course of the interaction: discourse, situational and transportable identities.

Discourse identities are discursive roles like 'current speaker', 'questioner', 'answerer', 'story teller', and 'listener'. Speakers assume and 'leave' discourse identities as the interaction progresses through various, sequentially organized discursive activities. Through assuming one particular discourse identity speakers project reciprocal discourse identities for their interlocutors. For example, the 'questioner' projects a hearer identity of 'answerer' for the next turn.

Situational identities are evoked by particular, socially-sanctioned types of situations, such as, e. g., 'the research interview'. In the research interview, the identities of 'researcher/interviewer' and 'informant/interviewee/informant' are sustained by the participants' engagement in discursive activities that display an orientation to and alignment with the situation type 'research interview'. Situational identities are articulated through particular discourse identities which help to shape the interaction as an actualization of the situation type. Hence, in the research interview, the discourse identity of 'questioner' is more firmly associated with the situational role of the researcher/interviewer than the role of the informant/interviewee.

Transportable identities, finally, "travel with individuals across situations" (Zimmerman 1998: 90). They are 'latent' identities in that they are usually easily assignable and claimable by participants in an interaction because they are based on accessible indicators of identity. But in contrast to discourse and situational identities, they are not inherent to an interaction and may or may not become interactionally relevant. For example, the interviewees in the present data may both claim and assign the identity of 'migrant' to themselves and the interviewer, but these categorizations may not become linguistically visible or interactionally relevant. Zimmerman suggests, however, that even the apprehension of a particular transportable identity in the interlocutor may influence the course of the interaction.

In the present data, the situational roles of researcher/interviewer and informant/interviewee interact in specific ways with the transportable identities the participants bring to the interview encounter. In fact, the informants were selected and agreed to take part in the interviews on the basis of being assigned the transportable identity of 'migrant' by the researcher and having claimed it themselves by accepting the invitation to take part. At the same time, in the process of negotiating participation in the interviews, the researcher had to disclose information about herself and the research, which - whether explicitly claimed or not - provided a transportable identity of 'migrant' for the interviewer as well. Even if it is not overtly oriented to by the interviewer in the interview itself, this identity can still be described as subject to 
apprehension on the part of the informants/interviewees. Consequently, it can be assumed that the interviewees' identity categorizations for the interviewer and the other participants in the group setting might come to play a role in the course of the interview encounter: The interviewees may recognize that their co-participants can be classified in a particular way. This tacit assignment may remain latent and irrelevant for the interaction until, for some reason, an interviewee orients to this classification and makes it relevant. One way in which the interviewees show an orientation to the transportable identities of their co-participants is codeswitching. In these cases the situational and transportable identities interact, because the speaker appeals to extra-situational knowledge assumed to exist in the transportable identity of the interlocutor(s).

\section{$3 \quad$ Code-switching}

The analysis of code-switching in the interview data followed Myers-Scotton's Matrix Language Frame Model (Myers-Scotton 1993). The majority of code-switches from the English matrix language into German are insertions, in which L1/L2 German elements are embedded in the English matrix language frame. Code-switching occurs when the interviewees talk about individual experiences with German society and culture or describe general differences between German and US-American society and culture. These accounts involve talk about third parties, which takes the form of reference to specific individuals, generic representatives of the cultures, or supra-individual social entities (institutions) and cultural constructs (nationals, nationalities, value systems). Compare examples (1) to (3) below.

Example (1) Talk about generic representatives

Group interview; L1 German; switch into L1

M It's the everyday life here uh the common task that you have to do everyday like going shopping or whatever is just easier, simpler here and Germans manage to turn this into a problem

G (laughs)

$M \quad$ the shopping experience can turn into something traumatically confusing and displeasing and annoying just because people give you

$G$ friendly

they are not as

M a feeling that they don't like you and that you're not supposed that you have the wrong hair color or whatever that you don't fit into this part of society and they give this to you this attitude and often when shopping in Germany I have the feeling that sorry for shopping here!?

$G$

König?

(laughs) it's not like wie sagt man noch der Kunde ist

M right!

Example (2) Talk about specific persons

Individual interview; L1 English; switch into L2

$J \quad$ especially coming from South Africa (.) which is I think like the U.S. in that we did a lot of things together (.) my boss there we also had dinner you know privately with his family or we had a an outing in our department and here I asked my boss I said well how many times do we do things together as a company and he said oh once a year we have a Betriebsausflug and that was a he was very proud and I was surprised that we DIDN'T have more things um (2.0) 
Example (3) Talk about cultural construct

Individual interview; L1 English; switch into L2

W but I just it was so clear to me that this whole working environment here is just not my style you know it's MUCH more rigid it's MUCH more hierarchical MUCH more male-dominated um these Betriebsrat things Betriebs(data) I mean I've never heard of anything more idiotic in my life you know and the stories Martin comes back with what they need to deal with with their Betriebsrat is just you have to ASK them if you can HIRE this Ausbildungs person? And they have to pr= what insanity is that?

The German-language insertions in these examples seem to be employed because the speakers feel that the equivalent expressions in the matrix language (i. e. English) do not capture the denotational and connotational meaning the German expressions convey and do not fulfil the interactional goals the speakers pursue at that point. These uses of code-switching are interaction-driven and socially motivated. They have to be distinguished from compensatory loan word usage, where lexemes and longer expressions are taken from another language as a consequence of L1 loss or lack of proficiency in the L2 (Du Bois 2010b).

The code-switching in the interviews can be described as the meaningful alternation between two languages which the speakers can assume all participants in the interaction to be proficient in. This type of code alternation has been referred to as "switching as a marked choice" (Myers-Scotton 1988: 62, 2006) or "metaphorical code-switching" (Gumperz 1982: 60-61). In these cases, the switches serve as contextualization cues for the interlocutors (Gumperz 1982: 98). The violation of conventionalized co-occurrence expectations between the content and the linguistic surface (i. e. monolingual talk) signals that another set of contextual presuppositions is involved in utterance production and interpretation (Gumperz 1982; MyersScotton 2006). In this way, the juxtaposition of two different linguistic systems generates conversational inferences which target underlying, unverbalized meanings that speakers assume to exist in their interlocutors. In the present case, this assumption rests on the basis of a perceived common ground of shared cultural knowledge between the speakers and the coparticipants in the interview encounter. The degree of shared common ground that a speaker can assume is dependent on the speaker's identity categorization for the co-participants. In this sense, code-switching as a means of interactional meaning making in the interviews is enabled by the transportable identities the interviewees apprehend in their interlocutors.

Code-switching has also been described as a marker of evaluation (Ochs/Schieffelin 1989; Bock 2008). Evaluation refers to the expression of the speakers' attitude or stance towards, viewpoint on or feelings about the entities and propositions they are talking about (Hunston/Thompson 1999). The expression of evaluation reflects the speakers' value system and constructs and maintains specific interpersonal relations between the speakers and their interlocutors. In her study on linguistic markers of evaluation in testimonies at the Human Rights Violation hearings of South Africa's Truth and Reconciliation Commission, Bock (2008) has shown that evaluation through code-switching is used by speakers to position absent others, i. e. those represented by or in the code-switch, as fundamentally different from the speakers and to emphasize this difference for their interlocutors. In these cases, codeswitching serves as a distancing mechanism and, at the same time, it constructs the 'other' in an almost palpable, authentic manner in the discourse. In sum, code-switching is a means of discursively highlighting the entity or proposition connected with the code-switch and of creating speaker-hearer alignment. It foregrounds the speaker's subjective perspective in discourse, makes explicit the speaker's assumption of common ground with the interlocutors, and invites them to share the speaker's point of view. 


\section{$4 \quad$ Talking about absent third parties in interviews}

As briefly touched upon in the previous section, talk about third parties occurs as talk about specific individuals, generic representatives of German and US-American culture, supra-individual social entities (institutions) and cultural constructs (nationalities, nations, value systems). Where the talk concerns persons, the interviewees talk about fellow migrants, friends and families, and institutional and generic representatives of the host and home cultures. Frequently, the informants' in-laws are invoked as particularly typical or atypical representatives of the host culture.

In the interview situation, talking about third parties involves potentially face-threatening elements. This risk factor is partly owed to the transportable identity of 'fellow migrant' which the interviewees can apprehend in the co-participants, and partly to the fact that reporting on individual experiences with and personal views on persons, society and culture inevitably involves expressing evaluations. Interview questions such as "what were difficulties you had interacting with German people when you first came here?" or "could you say what it was that you wanted to leave?" target the interviewees' individual experiences with and subjective attitudes towards Germany, the US, Americans, Germans, and their migration experience. In other words, the questions elicit the interviewees' opinions. In responding to these questions, the interviewees cannot be sure whether the interlocutors concur with their opinion about the third party or whether they possibly share characteristics of the third party that is brought up and evaluated.

This risk of face threats is especially high in the individual interviews with American migrants in Germany for two reasons: First, the interviewer carries both the transportable identity of 'fellow migrant' and 'representative of the German host culture', which makes assumptions of common ground regarding a shared value system on the part of the interviewee somewhat less secure. Secondly, due to the epistemological character of research interviews, meaning making in this speech genre is less subject to interactive negotiation. As a consequence, the interviewees' utterances stand out prominently as 'this specific person's personal opinion on a specific matter'. This is in contrast to the group interview setting, in which individual opinions have numerically more chance of finding positive uptake. Individual opinions can also be changed through negotiation with the other participants; and the participants can collaboratively construct a majority opinion, which makes an individual's stance necessarily less visible. In addition, in the present data, all participants in the group interviews share the same transportable identity of 'German immigrant in the US', which provides the participants with a clearer sense of shared common ground.

Talk about third parties occurs with and without code-switching in the interview data. In examples (1), (2), and (3) above the interviewees use code-switches to refer to Germans and German culture for the evaluation of specific conventions related to shopping and work life. The third parties are evaluated in terms of 'goodness' (examples (1) and (3)) and 'expectedness' (example (2)). The code-switches themselves, however, are not overtly evaluative. They only acquire evaluative meaning from their context of occurrence. In each example, they are embedded in a complex process of evaluating the interviewee and the third parties and positioning the interviewee in relation to the third parties. Through this, the interviewees convey their stance towards the third parties. The interviewees engage in this process for the purpose of presenting their self-identity to the interlocutors. In order to explain the role of the codeswitching in this context, it is necessary to uncover the mechanics of the patterns of evaluation and positioning around the code-switches in the interviewees' talk. In the following section, we briefly outline the concepts of positioning and appraisal. They provide the framework for our analysis of code-switching in talk about absent third parties in section 6 . 


\section{$5 \quad$ Positioning and appraisal analysis}

\subsection{Positioning analysis}

The function of talk about absent third parties in interaction has been most thoroughly addressed in research on positioning in discourse, especially in narrative discourse (cf. e. g. Bamberg 1996, 1997, 2000). For the purposes of the analyses in this study we use a simplified version of the model proposed by Lucius-Hoene and Deppermann (2002, 2004).

In one of the earliest formulations, positioning has been described as the "discursive process whereby [speakers, listeners and third parties'] selves are located in conversations as observably and subjectively coherent participants in jointly produced story lines" (Davies/Harré 1990: 48). In communicative interaction, interactional activities have a referential-informative function and, at the same time, serve the speakers' identity construction and the speakers' selfpresentation vis-à-vis their interlocutors. Speakers position themselves in relation to their interlocutors through talking, and in doing so they construct themselves and their interlocutors as social beings (Bamberg 1997).

Identity construction and self-presentation are realized by speakers' self- and other-positioning in discourse. Self-positioning refers to discursive practices which convey to the interlocutors that the speaker claims a particular social position, role or identity ${ }^{1}$. Other-positioning refers to the construction of a social position, role or identity for entities other than the speaker. These other persons include the interlocutors as well as absent third parties.

It's important to note that the 'speaker' can be either the interviewee in the actual communicative encounter (i. e. the interview situation) or a third party in the events that are reported on. ${ }^{2}$ A statement like "this whole working environment here [...] it's MUCH more rigid it's MUCH more hierarchical MUCH more male-dominated" in example (3) above is talk about third parties that falls into the category of other-positioning, where the speaker is the interviewee in the interview situation. When the talk about third parties involves reports of past events, the interviewee can use reported speech to have the third parties position themselves ("and he said oh once a year we have a Betriebsausflug", example (2)). Finally, interviewees can present themselves as other-positioned by a third party ("and they give this to you this attitude", example (1)). Thus, talk about third parties can occur in three forms in interviewees' discourse:

1. Other-positioning of the third party by the interviewee

2. Self-positioning of the third party in the form of reported self-referential talk by the third party

3. Other-positioning of the interviewee by the third party

Positioning constructs speakers and others in discourse as socially identifiable persons in that it shows how speakers see themselves in relation to others and which attributes, roles and characteristics they claim for themselves and assign to others. Self- and other-positioning are interdependent parts of a speaker's positioning practice. A speaker's self-positioning in discourse implicates the interlocutors'/third parties' other-positioning. That is, in claiming an identity for themselves, speakers allocate particular identities to others because identity work involves alignment and disalignment with others. Conversely, a speaker's other-positioning of

\footnotetext{
1 The terms 'identity', 'social position' and 'role' are used interchangeably here.

2 In Lucius-Hoene and Deppermann's $(2002,2004)$ terms the speaker can be either the "narrating I" or an "interactant in the story". The terms "narrating I" and "story" are avoided here because positioning also occurs outside narratives in the interviews. (See Du Bois (2010a) for detailed analyses of story-telling in the interviews.)
} 
interlocutors/third parties and the positioning acts ascribed to third parties implicate a simultaneous claim to a specific social position for the speaker.

Lucius-Hoene and Deppermann (2004) claim that speakers' positioning practices usually concern both the actualization of an identity that existed before the interaction - similar to Zimmerman's "transportable identities" - and the construction of a situated identity, which emerges in and through the interaction. Thus, self- and other-positioning are dependent on speakers' assumptions about their interlocutors' knowledge, attitudes, beliefs, interests and needs in relation to the transportable and situated identities that are instantiated in discourse.

Self- and other-positioning are achieved through individual positioning acts (Figure 1). They can refer to

- the relation between interviewee and interviewer (and other interviewees in the group setting);

- the relation between interviewee and a third party.

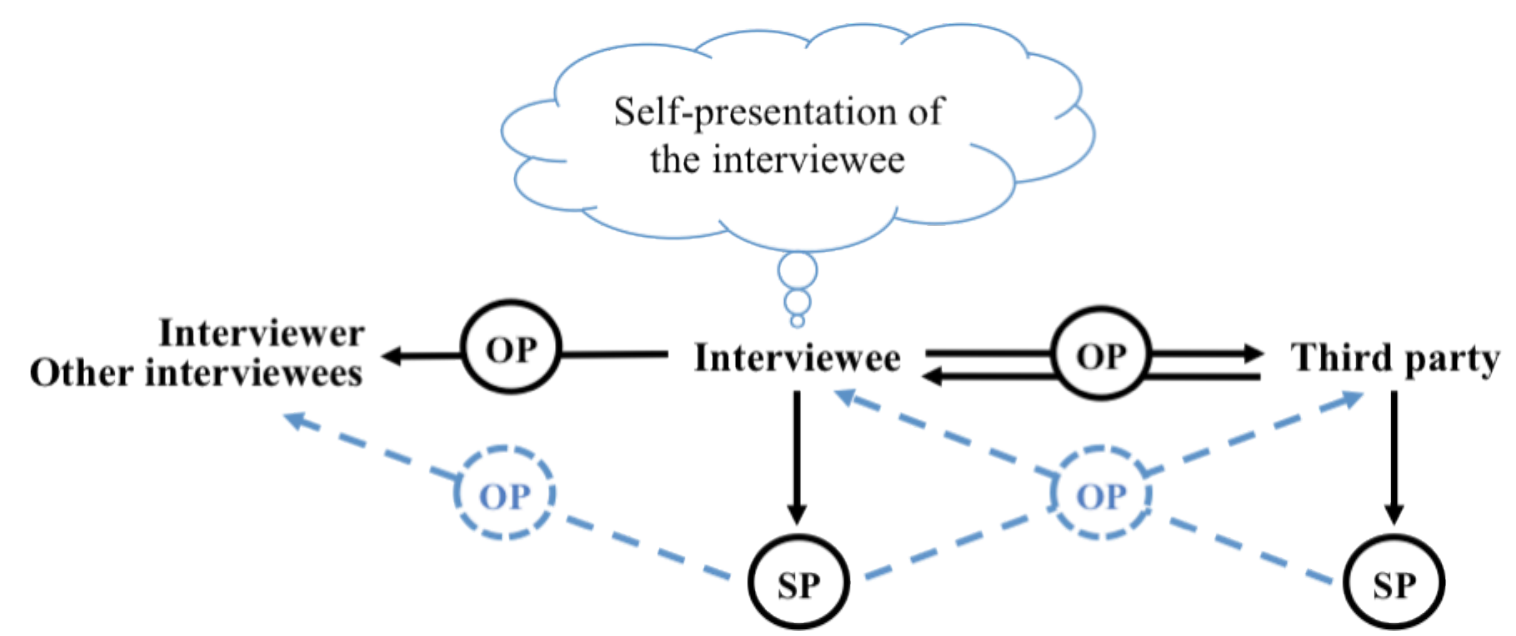

Figure 1: Self- and other-positioning in the interview setting. $\mathrm{SP}=$ self-positioning; $\mathrm{OP}=$ other-positioning; dotted lines $=$ potential implicated positionings

Positioning acts are claims to identities. They can be direct and explicit, and indirect and implicit, depending on interpretation and inference. In an interaction, each positioning act is either accepted, partly accepted or rejected by the co-participants. Positioning analysis, then, is concerned with the linguistic and extralinguistic devices that realize positioning acts. The framework of appraisal analysis (Martin/White, 2005) allows us to look systematically at the role that evaluation plays in a speaker's positioning practice.

\subsection{Appraisal analysis}

Appraisal analysis has been developed in the framework of Systemic Functional Grammar to account for evaluation in language. It is concerned with the way language is used to evaluate, to adopt stances, to construct textual personas and to manage interpersonal positioning and relationships. It explores how attitudes, judgements and emotive responses are explicitly presented in texts and how they may be more indirectly implied, presupposed or assumed (White 2005).

The term 'appraisal' acts as cover term for the linguistic means by which speakers (and writers) positively or negatively evaluate persons, events, things, states-of-affairs and propositions in order to "express, negotiate and naturalize particular intersubjective and ultimately ideo- 
logical positions" (White 2005: para. 1). The concept is fundamentally interaction-oriented in that it is assumed that all acts of evaluating in discourse aim at constructing relations of alignment and rapport between the speaker/writer and actual or potential addresses (Martin/White 2005).

Appraisal analysis is concerned with aspects of language and language use that are usually described separately from each other, under the headings of affect, emotivity, evidentiality, modality, intensification, and vague language. With its roots in Systemic Functional Grammar, appraisal analysis works along networks of systems of functional categories. The appraisal system is shown in Figure 2 below. For the present purposes, the focus is on the system of 'attitude', which encompasses the expression of affect and emotivity, i. e. the evaluation of something or somebody in a speaker's discourse through the expression of different types of positive and negative feelings (Figure 3).

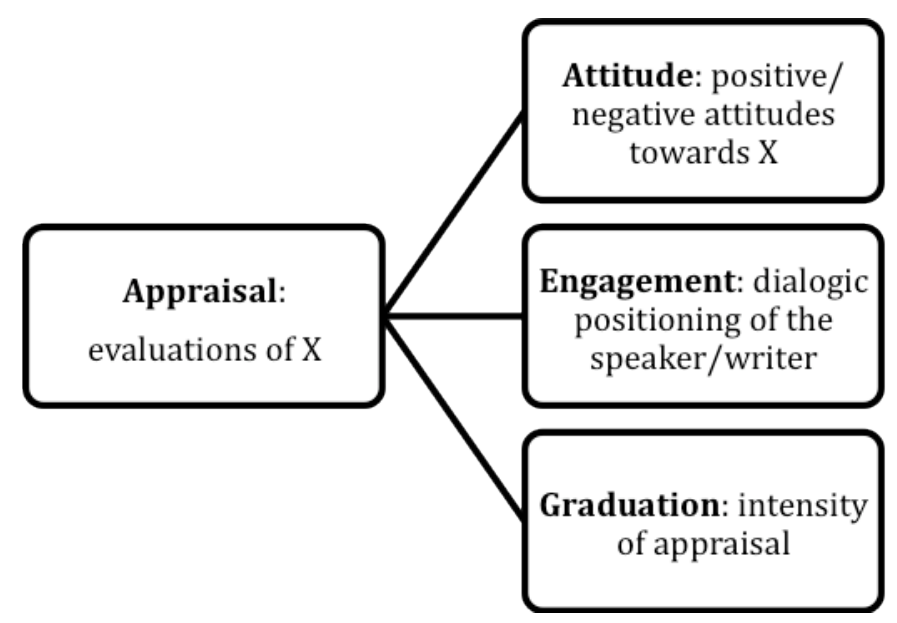

Figure 2: Appraisal system network 


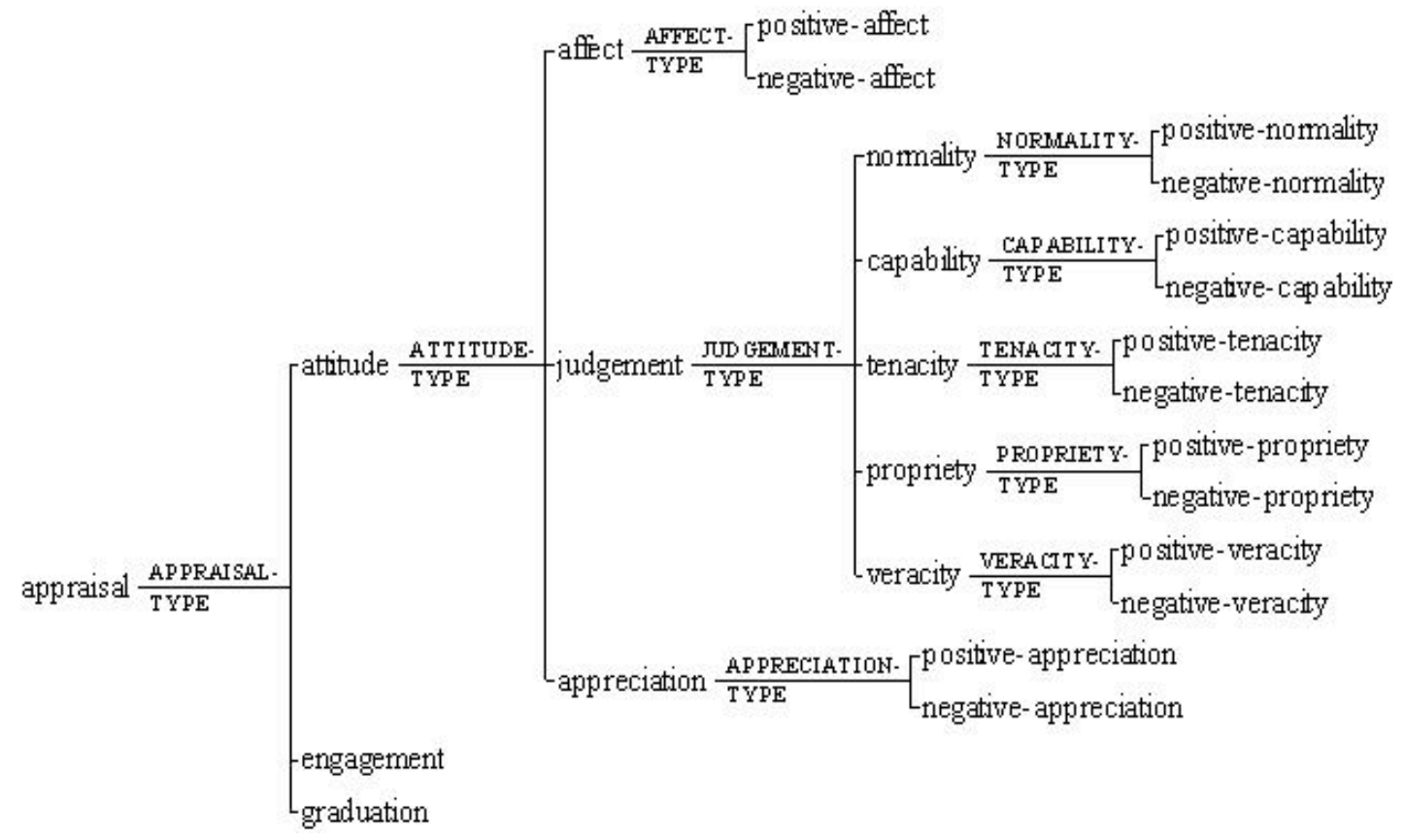

Figure 3: Appraisal system network: Attitude

Within the appraisal model the expression of an attitude can be categorized as an expression of affect, judgement, or appreciation. Affect refers to the speaker's expression of a positive/negative feeling or affective state towards a person, thing, event, or proposition. Judgement refers to the expression of admiration or criticism towards persons and their behaviour with respect to normality, capability, tenacity, propriety, and veracity. Judgements are based on implicit or explicit, socially sanctioned norms of conventional and expectable behaviour. Finally, appreciation refers to positive or negative assessments of things and phenomena according to an aesthetic value system.

Appraisal can be overt and explicit ("inscribed") or, in the absence of attitudinal lexis, covert and implicit ("invoked") (Martin/White 2005: 61-62). Invoked appraisal is subject to interpretation and inferencing. The interpretation of implicit appraisal is dependent on the socalled reading position of the addressee. The reading position is defined by the set of accessible contextual presuppositions, which are tied to the transportable and situational identities of the addressee, i. e. in the present context particularly the identities of interviewer, researcher, compatriot, fellow migrant. In sum, in an appraisal analysis, implicit or explicit evaluative features in individual propositions are categorized according to the type of evaluation they express in their context of occurrence. In the following section, we will combine positioning analysis and appraisal analysis in order to explain the function of code-switching in talk about absent third parties.

\section{Three examples}

\subsection{Man tut das nicht ('you don't do that')}

Example (4) Individual interview; male; thirty years in Germany; L1 English; switch into L2

Int so what were some other difficulties you had um interacting with German people when you first came here 
D I've always been very open (.) very little just little things like (.) you cannot take things back to the store if it's not any good returning things

helped change it the first week back the first week over um I was sitting there with my future wife um that I married 3 years later I think um we opened some cheese up and the cheese was all mouldy-it wasn't s'posed to be it wasn't Danish blue or anything and I couldn't believe it and I said I'll take that back and she says "Ne ist Pech"i you know just a problem just bad luck I said "What do you mean bad luck?" and I said I'm gonna take it back to the store I have the receipt and she said "No-one does that here" and I did it and there was no problem (.) so my wife has sort of a post-war always had a sort of post-war mentality of "Man tut das nicht"ii You don't do that you can't do that when we had we wanted to go to Finland we had the tent I wanted to put the tent up in her parents' yard which was all rented apartments in Bergedorf and "Das kannst du nicht machen'iii you can't put the tent up there because the neighbors would get upset cos it might kill the grass I said "For an HOUR?" so it was my wife telling me things that you shouldn't do because the neighbours wouldn't like it or certain things and I couldn't I couldn't believe that and I did a lot of returning in Germany and I almost made it a sport just because I was told that you couldn't do it (.) but I've I tend to I tend to respect cultures and if something makes sense to me I'll go along with it (.)

\footnotetext{
i 'no it's just bad luck'

ii' $y$ ou don't do that'

iii' you can't do that'
}

The co-occurrence of appraisal and positioning acts is presented in Table 1 below. Talk about third parties occurs as other-positioning (OP) in column (4) and as self- and other-positioning (OP; SP) in column (5). It contrasts with self-referential talk, i. e. self-positioning, by the speaker (SP in column 4).

\begin{tabular}{|c|c|c|c|c|}
\hline & & Appraisal & $\begin{array}{l}\text { Positioning of the } \\
\text { speaker ("narrating } \\
\text { I/ narrated I") }\end{array}$ & $\begin{array}{l}\text { Positioning of the } \\
\text { third party }\end{array}$ \\
\hline 1 & 2 & 3 & 4 & 5 \\
\hline Int1 & $\begin{array}{l}\text { so what were some other difficulties } \\
\text { you had um interacting with } \\
\text { German people when you first came } \\
\text { here }\end{array}$ & & & \\
\hline D1 & I've always been very open (.) & $\begin{array}{l}\text { positive judgement } \\
\text { of speaker's } \\
\text { propriety }\end{array}$ & SP & \\
\hline D2 & $\begin{array}{l}\text { very little just little things like (.) } \\
\text { you cannot take things back to the } \\
\text { store if it's not any good returning } \\
\text { things }\end{array}$ & $\begin{array}{l}\text { negative judgement } \\
\text { of normality }\end{array}$ & & $\begin{array}{l}\text { OP of stores in Ger- } \\
\text { many }\end{array}$ \\
\hline Int 2 & That changed though & & & \\
\hline D3 & $\begin{array}{l}\text { I know and I helped change it the } \\
\text { first week back the first week over } \\
\text { um I was sitting there with my } \\
\text { future wife um that I married } 3 \\
\text { years later }\end{array}$ & $\begin{array}{l}\text { positive appreciation } \\
\text { of speaker's actions }\end{array}$ & SP & \\
\hline
\end{tabular}




\begin{tabular}{|c|c|c|c|c|}
\hline & & Appraisal & $\begin{array}{l}\text { Positioning of the } \\
\text { speaker ("narrating } \\
\text { I/ narrated I") }\end{array}$ & $\begin{array}{l}\text { Positioning of the } \\
\text { third party }\end{array}$ \\
\hline 1 & 2 & 3 & 4 & 5 \\
\hline $\mathrm{D} 4$ & $\begin{array}{l}\text { I think um we opened some cheese } \\
\text { up and the cheese was all mouldy- } \\
\text { it wasn't s'posed to be it wasn't } \\
\text { Danish blue or anything and I } \\
\text { couldn't believe it }\end{array}$ & negative affect & SP & \\
\hline D5 & $\begin{array}{l}\text { and I said I'll take that back and she } \\
\text { says "Ne ist Pech" you know just a } \\
\text { problem just bad luck }\end{array}$ & negative affect & & SP of German wife \\
\hline D6 & $\begin{array}{l}\text { I said "What do you mean bad } \\
\text { luck?" and I said I'm gonna take it } \\
\text { back to the store I have the receipt }\end{array}$ & $\begin{array}{l}\text { positive judgement } \\
\text { of capacity }\end{array}$ & SP & \\
\hline D7 & $\begin{array}{l}\text { and she said "No-one does that } \\
\text { here" }\end{array}$ & $\begin{array}{l}\text { negative judgement } \\
\text { of normality/ } \\
\text { propriety }\end{array}$ & & SP of German wife \\
\hline D8 & and $I$ did it & $\begin{array}{l}\text { positive appreciation } \\
\text { of speaker's action }\end{array}$ & SP & \\
\hline D9 & and there was no problem & $\begin{array}{l}\text { positive judgement } \\
\text { of speaker's } \\
\text { capability }\end{array}$ & & $\begin{array}{l}\text { OP of German wife } \\
\text { (implicated) }\end{array}$ \\
\hline D10 & $\begin{array}{l}\text { (.) so my wife has sort of a post- } \\
\text { war always had a sort of post-war } \\
\text { mentality of "Man tut das nicht" }\end{array}$ & $\begin{array}{l}\text { negative judgement } \\
\text { of normality }\end{array}$ & & OP of German wife \\
\hline D11 & You don't do that you can't do that & $\begin{array}{l}\text { negative judgement } \\
\text { of normality }\end{array}$ & & OP of German wife \\
\hline D12 & $\begin{array}{l}\text { when we had we wanted to go to } \\
\text { Finland we had the tent I wanted to } \\
\text { put the tent up in her parents' yard } \\
\text { which was all rented apartments in } \\
\text { Bergedorf and "Das kannst du } \\
\text { nicht machen" }\end{array}$ & $\begin{array}{l}\text { negative judgement } \\
\text { of normality/ } \\
\text { propriety }\end{array}$ & $\begin{array}{l}\text { OP by German } \\
\text { wife }\end{array}$ & SP of German wife \\
\hline D13 & you can't put the tent up there & $\begin{array}{l}\text { negative judgement } \\
\text { of normality/ } \\
\text { propriety }\end{array}$ & $\begin{array}{l}\text { OP by German } \\
\text { wife }\end{array}$ & SP of German wife \\
\hline D14 & $\begin{array}{l}\text { because the neighbors would get } \\
\text { upset cos it might kill the grass }\end{array}$ & $\begin{array}{l}\text { negative judgement } \\
\text { of normality/ } \\
\text { propriety }\end{array}$ & & $\begin{array}{l}\text { OP of German } \\
\text { neighbours }\end{array}$ \\
\hline D15 & I said "For an HOUR?" & $\begin{array}{l}\text { negative judgement } \\
\text { of normality }\end{array}$ & SP & \\
\hline D16 & $\begin{array}{l}\text { so it was my wife telling me things } \\
\text { that you shouldn't do because the } \\
\text { neighbours wouldn't like it or } \\
\text { certain things }\end{array}$ & & & OP of German wife \\
\hline D17 & and I couldn't I couldn't believe that & $\begin{array}{l}\text { negative judgement } \\
\text { of normality }\end{array}$ & SP & \\
\hline D18 & $\begin{array}{l}\text { and I did a lot of returning in } \\
\text { Germany and I almost made it a } \\
\text { sport }\end{array}$ & $\begin{array}{l}\text { positive appreciation } \\
\text { of speaker's actions }\end{array}$ & SP & \\
\hline
\end{tabular}




\begin{tabular}{|c|c|c|c|c|}
\hline & & Appraisal & $\begin{array}{l}\text { Positioning of the } \\
\text { speaker ("narrating } \\
\text { I/ narrated I") }\end{array}$ & $\begin{array}{l}\text { Positioning of the } \\
\text { third party }\end{array}$ \\
\hline 1 & 2 & 3 & 4 & 5 \\
\hline D19 & $\begin{array}{l}\text { just because I was told that you } \\
\text { couldn't do it (.) }\end{array}$ & & & OP of German wife \\
\hline D20 & $\begin{array}{l}\text { but I've I tend to I tend to respect } \\
\text { cultures }\end{array}$ & $\begin{array}{l}\text { positive judgement } \\
\text { of speaker's } \\
\text { propriety }\end{array}$ & SP & \\
\hline D21 & $\begin{array}{l}\text { and if something makes sense to me } \\
\text { I'll go along with it (.) }\end{array}$ & $\begin{array}{l}\text { positive judgement } \\
\text { of speaker's } \\
\text { propriety }\end{array}$ & SP & \\
\hline
\end{tabular}

Table 1: Appraisal and positioning acts. $\mathrm{SP}=$ self-positioning; $\mathrm{OP}=$ other-positioning; italics = inscribed/invoked appraisal; bold = propositions with code-switching

D's account is the response to the interviewer's question about difficulties in interacting with Germans shortly after his arrival in Germany. The account serves to assess specific social practices in Germany and to put the speaker in relation to them. Specifically, he presents himself as carrier of 'normal' and 'proper' values. To this end, he re-counts experiences of conflicts with Germans which were grounded - in his view - in cross-cultural differences between Germany and the US.

The absent third parties talked about are D's German wife, shops in Germany and the neighbours of D's in-laws in Germany. The interaction between appraisal and positioning acts construct a contrast between American and German ideas of what constitutes 'normal' and 'proper' behaviour and how to react to negative life-experiences ("mouldy cheese"): The interviewee's self-positioning is connected with positive evaluations of the 'normality' of his behaviour. The self-positioning of D's German wife is connected with negative evaluations of German practices in terms of their 'normality'. The other-positioning of third parties (wife, neighbours, shops) is connected with negative evaluations of the third parties' 'normality'. The other-positioning of the interviewee by the third parties is connected with negative evaluations of the 'propriety' of his behaviour.

The code-switches into German occur after an objection by the interviewer ("That changed though", Int2) to a generalized negative evaluation of German stores by the interviewee. At that moment, the interviewer posits herself as knowledgeable about current social practices in Germany and willing to challenge the interviewee's view. The interviewer concurs (D3) and then re-traces his argument by providing specific examples of experiences with Germans in the past, positing the code-switches as quasi verbatim evidence for his assessment.

The contrast which the speaker establishes between German and American practices is emphasized and intensified by the code-switches. At the same time, the code-switches are routine-like, formulaic expressions in German, which have a high recognition value for the interviewer. They are typically associated with the expression of general and binding restrictions on social behaviour, grounded in traditional, conservative, middle-class conceptions of normality and propriety. However, these connotations only work properly between interlocutors who are highly proficient in German and have considerable background knowledge about past and present social structure in Germany. The code-switches presuppose this kind of knowledge in the interviewer and position her as someone who is knowledgeable in this respect, $\mathrm{i}$. e. able to decode the intended meanings.

By locating the evaluative accounts of German third parties in the past, the interviewee avoids extending the contrast between himself as a representative of values that are different from 
what used to be 'normal' in Germany into the present of the interview encounter. This reduces the contrast between his position and the one of the interviewer and deflects the focus away from potential differences between their transportable identities, which are important moves in the light of the interviewer's initial objection to his evaluation. In sum, through the codeswitches the interviewee maximizes the contrast between himself and the third parties and achieves a relatively clear-cut positive-negative categorization of American and German social practices. The culture-specific connotations of the German expressions serve to help the interviewer to arrive at the interpretation of the reported events intended by the interviewee.

\subsection{Ausländers ('foreigners')}

Excerpt (5) Individual interview; female; two years in Germany; L1 English; switch into L2

Int so have you encountered any other difficulties besides um shopping@@

$W$

I hate shopping here

Int any other um

$W$

Int

$W$

um (.) that's a tough $q u=I$ mean (.)

or any surprises

you know everyone says that the Germans are so difficult to get to know and um I would sort of in contrast to the American sort of open the arms and for example neighbourhood in the U.S. it's much more common you know your neighbours you know and you help each other out a lot and you know you move in and all your neighbours come over and bring you welcome gifts and the welcome wagon comes and brings you you know a big basket of things to help you move into the neighbourhood it's this it's a very different neighbourhood kind of thing and here it's not that (.) um we know these are relatives here on this side and they've been tremendously helpful and we know these people here um because they have a daughter that plays with my daughter um but I wouldn't necessarily say that you know we're not good friends and everyone else well they're not well many of them are much older you know still we even had you know our neighbours Martin's uncle threw a party for us in the beginning a little brunch yeah and had a bunch of the neighbours invited but even though we've met them you know it's still sort of like I hardly TALK to them any time and they would never then invite YOU to a party so this concept of having this group of people in the neighbourhood that just because they live near each other they socialize doesn't exist (.) and then (.) it's weird because you do then meet Germans and even with Martin and other relatives or friends that he might have just because they meet someone it doesn't mean that they open up their arms and include me in their social circle you really have to earn that over time over quite a while and once you get a good friend then you're a good friend and you've got parties to go to and things like that but um as an outsider I find that the other outsiders the other Ausländers are much more willing to bring you into their circle because they're here for a lot of them are here for a shorter period of TIME and you know they're looking for friends too and you know you immediately get swept up into a group of people who socialize and want to do things and you know um so you're much faster absorbed into that grouping than you are into the German group which just takes longer and you really really have to work at it 


\begin{tabular}{|c|c|c|c|c|}
\hline & & Appraisal & $\begin{array}{l}\text { Positioning of the } \\
\text { speaker } \\
\text { ("narrating I/ } \\
\text { narrated I") }\end{array}$ & $\begin{array}{l}\text { Positioning of the } \\
\text { third party }\end{array}$ \\
\hline 1 & 2 & 3 & 4 & 5 \\
\hline Int1 & $\begin{array}{l}\text { so have you encountered any } \\
\text { other difficulties besides um } \\
\text { shopping@@ }\end{array}$ & & & \\
\hline W1 & I hate shopping here & & & \\
\hline Int2 & any other um & & & \\
\hline W2 & $\begin{array}{l}\text { um (.) that's a tough qu= I mean } \\
\text { (.) }\end{array}$ & & & \\
\hline Int3 & or any surprises & & & \\
\hline W3 & you know everyone says that & & SP & \\
\hline W4 & $\begin{array}{l}\text { the Germans are so difficult to } \\
\text { get to know }\end{array}$ & negative affect & & OP Germans \\
\hline W5 & $\begin{array}{l}\text { and um I would sort of in } \\
\text { contrast to the American sort of } \\
\text { open the arms }\end{array}$ & $\begin{array}{l}\text { positive judgement } \\
\text { of normality }\end{array}$ & & OP Americans \\
\hline W6 & $\begin{array}{l}\text { and for example neighbourhood } \\
\text { in the U.S. it's much more } \\
\text { common you know your } \\
\text { neighbours }\end{array}$ & $\begin{array}{l}\text { positive judgement } \\
\text { of normality }\end{array}$ & & $\begin{array}{l}\text { OP American } \\
\text { neighbourhood in } \\
\text { the US }\end{array}$ \\
\hline W7 & $\begin{array}{l}\text { you know and you help each } \\
\text { other out a lot }\end{array}$ & $\begin{array}{l}\text { positive judgement } \\
\text { of normality; } \\
\text { capability }\end{array}$ & & $\begin{array}{l}\text { OP American } \\
\text { neighbourhood in } \\
\text { the US }\end{array}$ \\
\hline W8 & $\begin{array}{l}\text { and you know you move in and } \\
\text { all your neighbours come over } \\
\text { and bring you welcome gifts }\end{array}$ & $\begin{array}{l}\text { positive judgement } \\
\text { of normality }\end{array}$ & & $\begin{array}{l}\text { OP American } \\
\text { neighbourhood in } \\
\text { the US }\end{array}$ \\
\hline W9 & $\begin{array}{l}\text { and the welcome wagon comes } \\
\text { and brings you you know a big } \\
\text { basket of things to help you } \\
\text { move into the neighbourhood }\end{array}$ & $\begin{array}{l}\text { positive judgement } \\
\text { of normality }\end{array}$ & & $\begin{array}{l}\text { OP American } \\
\text { neighbourhood in } \\
\text { the US }\end{array}$ \\
\hline W10 & $\begin{array}{l}\text { it's this it's a very different } \\
\text { neighbourhood kind of thing }\end{array}$ & & & $\begin{array}{l}\text { OP American } \\
\text { neighbourhood in } \\
\text { the US }\end{array}$ \\
\hline W11 & and here it's not that (.) & $\begin{array}{l}\text { negative judgement } \\
\text { of normality }\end{array}$ & & $\begin{array}{l}\text { OP German neigh- } \\
\text { bourhood }\end{array}$ \\
\hline W12 & $\begin{array}{l}\text { um we know these are relatives } \\
\text { here on this side and they've } \\
\text { been tremendously helpful }\end{array}$ & $\begin{array}{l}\text { positive judgement } \\
\text { of capability; } \\
\text { positive affect }\end{array}$ & & $\begin{array}{l}\text { OP German in- } \\
\text { laws }\end{array}$ \\
\hline W13 & $\begin{array}{l}\text { and we know these people here } \\
\text { um because they have a daughter } \\
\text { that plays with my daughter um } \\
\text { but I wouldn't necessarily say } \\
\text { that you know we're not good } \\
\text { friends }\end{array}$ & $\begin{array}{l}\text { negative judgement } \\
\text { of normality }\end{array}$ & SP & \\
\hline
\end{tabular}




\begin{tabular}{|c|c|c|c|c|}
\hline & & Appraisal & $\begin{array}{l}\text { Positioning of the } \\
\text { speaker } \\
\text { ("narrating I/ } \\
\text { narrated I") }\end{array}$ & $\begin{array}{l}\text { Positioning of the } \\
\text { third party }\end{array}$ \\
\hline 1 & 2 & 3 & 4 & 5 \\
\hline W14 & $\begin{array}{l}\text { and everyone else well they're } \\
\text { not well many of them are much } \\
\text { older you know still we even had } \\
\text { you know our neighbours } \\
\text { Martin's uncle threw a party for } \\
\text { us in the beginning a little } \\
\text { brunch yeah and had a bunch of } \\
\text { the neighbours invited but even } \\
\text { though we've met them you know } \\
\text { it's still sort of like I hardly } \\
\text { TALK to them any time }\end{array}$ & $\begin{array}{l}\text { negative judgement } \\
\text { of normality }\end{array}$ & SP & \\
\hline W15 & $\begin{array}{l}\text { and they would never then invite } \\
Y O U \text { to a party }\end{array}$ & $\begin{array}{l}\text { negative judgement } \\
\text { of normality }\end{array}$ & & $\begin{array}{l}\text { OP German neigh- } \\
\text { bours }\end{array}$ \\
\hline W16 & $\begin{array}{l}\text { so this concept of having this } \\
\text { group of people in the } \\
\text { neighbourhood that just because } \\
\text { they live near each other they } \\
\text { socialize doesn't exist (.) and } \\
\text { then (.) it's weird because you do } \\
\text { then meet Germans and even } \\
\text { with Martin and other relatives } \\
\text { or friends that he might have just } \\
\text { because they meet someone it } \\
\text { doesn't mean that they open up } \\
\text { their arms and include me in } \\
\text { their social circle }\end{array}$ & $\begin{array}{l}\text { negative judgement } \\
\text { of normality }\end{array}$ & & $\begin{array}{l}\text { OP German } \\
\text { husband's friends }\end{array}$ \\
\hline W17 & $\begin{array}{l}\text { you really have to earn that over } \\
\text { time over quite a while }\end{array}$ & & & OP Germans \\
\hline W18 & $\begin{array}{l}\text { and once you get a good friend } \\
\text { then you're a good friend and } \\
\text { you've got parties to go to and } \\
\text { things like that }\end{array}$ & positive affect & OP by Germans & \\
\hline W19 & but um as an outsider I find that & & SP & \\
\hline W20 & $\begin{array}{l}\text { the other outsiders the other } \\
\text { Ausländers are much more } \\
\text { willing to bring you into their } \\
\text { circle because they're here for a } \\
\text { lot of them are here for a shorter } \\
\text { period of TIME and you know } \\
\text { they're looking for friends too }\end{array}$ & $\begin{array}{l}\text { positive judgement } \\
\text { of normality }\end{array}$ & & $\begin{array}{l}\text { OP outsiders, } \\
\text { foreigners in } \\
\text { Germany }\end{array}$ \\
\hline W21 & $\begin{array}{l}\text { and you know you immediately } \\
\text { get swept up into a group of } \\
\text { people who socialize and want } \\
\text { to do things }\end{array}$ & positive affect & $\begin{array}{l}\text { OP by outsiders, } \\
\text { foreigners in } \\
\text { Germany }\end{array}$ & \\
\hline W22 & $\begin{array}{l}\text { and you know um so you're } \\
\text { much faster absorbed into that } \\
\text { grouping }\end{array}$ & $\begin{array}{l}\text { positive judgement } \\
\text { of normality }\end{array}$ & $\begin{array}{l}\text { OP by outsiders, } \\
\text { foreigners in } \\
\text { Germany }\end{array}$ & \\
\hline
\end{tabular}




\begin{tabular}{lllll}
\hline & Appraisal & $\begin{array}{l}\text { Positioning of the } \\
\text { speaker } \\
\text { ("narrating I/ } \\
\text { narrated I") }\end{array}$ & $\begin{array}{l}\text { Positioning of the } \\
\text { third party }\end{array}$ \\
\hline 1 & 2 & 3 & 4 & 5 \\
\hline W23 & $\begin{array}{l}\text { than you are into the German } \\
\text { group which just takes longer } \\
\text { and you really really have to } \\
\text { work at it }\end{array}$ & $\begin{array}{l}\text { negative judgement } \\
\text { of normality }\end{array}$ & $\begin{array}{l}\text { OP by German } \\
\text { group }\end{array}$ & \\
& & &
\end{tabular}

Table 2: Appraisal and positioning acts. $\mathrm{SP}=$ self-positioning; $\mathrm{OP}=$ other-positioning; italics = inscribed/invoked appraisal; bold = propositions with code-switching

W's account is the response to the interviewer's question about difficulties she encountered after her arrival in Germany. The account, in which the interviewee reports experiences of social inclusion and exclusion, serves to assess socializing conventions and access to social groups in Germany and to put the speaker in relation to these. The third parties invoked for this purpose are Germans in Germany (in general, neighbours, husband's friends and family), Americans in the US, and foreigners in Germany.

The interaction between appraisal and positioning acts constructs the interviewee as an outsider to German society and member of a group of outsiders which contrast favourably with comparable German groups: The third parties occur predominantly in other-positionings by the interviewee. With the exception of the German in-laws, all Germans are associated with negative evaluations regarding the 'normality' of their behaviour. In contrast, the behaviour of Americans in the US is evaluated positively in terms of its overall 'normality'. Americans are also positively evaluated as 'capable'. The behaviour of foreigners in Germany is likewise associated with a positive evaluation of its 'normality'. The interviewee is also other-positioned by third parties, which is connected to both positive negative evaluations in the case of Germans (W18, W23) and throughout positive evaluations in the case of foreigners in Germany (W21/22). Interestingly, the self-positioning of the interviewee is connected to negative evaluations of the normality of her own behaviour in contact with Germans (W13/14).

The code-switch into German occurs in the context of the interviewer's positive evaluation of the 'normality' of the foreigners' behaviour, which at that point in the account contrasts distinctively with the less 'normal' behaviour she reported for the Germans of her acquaintance. The expression Ausländer ('foreigners') carries predominantly negative connotations in German. It conveys meanings of segregation, seclusion of the native majority, and an unwillingness or incapacity to integrate into German society on the part of the people referred to with the term. It can be used to stigmatize foreigners as strangers and aliens in German society. The use of the expression, thus, invokes a particularly pronounced contrast between German natives and foreigners in Germany in general and the Germans and foreigners in the interviewee's account in particular.

The code-switch occurs as a repair to "outsiders". The term 'outsider' refers to a person who does not belong to a particular group and also carries mainly negative connotations, which are, however, not primarily grounded in ethnic or national categories. Through the codeswitch the interviewee posits and highlights the national dimension as the reason for being outside and not belonging. It can be assumed that the interviewee knows about the culturespecific connotations of Ausländer and uses the code-switch strategically in the positive evaluation of a group of people which behaves differently, and more 'normal', than comparable German groups in her environment. In other words, the interviewee uses a negative term, which can be used to stigmatize foreigners as 'less normal' than natives, in order to denote a group of foreigners to which she ascribes thoroughly positive and, crucially, 'normal' charac- 
teristics. The interviewee uses the term Ausländer further to construct herself as a member of the group of foreigners in Germany. By positioning herself as part of a typically stigmatized group, she creates a stark contrast between herself and Germans in general. For the L1 listener, i. e. the interviewer, the term and the unconventional context in which it is used heightens the contrast between Germans on the one side and Americans and foreigners in Germany on the other.

\subsection{Mittagessen ('lunch')}

Excerpt (6) Group interview; five to ten years in the US; L1 German; switch into L1

$B \quad$ Yeah maybe but I think you're right I mean talking about everybody in Europe in the Middle Ages it was all horrible there were a lot of brutality and everything but I do think you know I don't know I believe that I believe that it gets passed down you know and that it hasn't faded yet or it's just slowly fading and I think that's why we have a lot of bitterness and fear and guilt and that's what's so toxic to find happiness

$G$

but not so

much the young generation, it's more our parents and grandparents of course but I think the side is in general a little more stiff more stiff there are not to say that it's not conservative here in some ways it is but in Germany I think if it comes to living the way Germans live together it's still very conservative so uhm they're less casual about it and so here it's just up to you you know uhm people that Germany is

$G \quad y e s$

$M$

in general the bay area of course is different America is much more right wing West right uhm well I didn't mean to go there but just in general in terms of like you know like in Germany you still find families in they have like Mittagessen ${ }^{i}$ I mean it's still like you don't come to their house you don't disturb there's Mittagsruhe ${ }^{i i}$ or after a certain time you do not call you don't find I mean

G Yeah so it's

A Tagesschau ${ }^{i i i}$ !

$G$

(All laugh)

\section{Yeah}

$G \quad$ or you know you know when you have lunchtime and people sometimes in Germany really they ask the guest to leave it

Yeah

G

it's really true I mean I don't wanna (?) on it but it's really family time and uhm and has changed of course so I don't think you would find that here

$B$ My parents [do that too my mom never would invite people over for lunch for

$G \quad$ [ja yeah yeah

$B \quad$ Mittagessen she was really mean go home (?) [it's not

$G \quad$ [(?) They are not trying to be mean, it's just their culture it's just the way they were brought up

i'lunch'

${ }^{i i}$ period of rest around midday

${ }^{i i i}$ prime time news broadcast 


\begin{tabular}{|c|c|c|c|c|}
\hline & & Appraisal & $\begin{array}{l}\text { Positioning of the } \\
\text { speaker } \\
\text { ("narrating I/ } \\
\text { narrated I") }\end{array}$ & $\begin{array}{l}\text { Positioning of the } \\
\text { third party }\end{array}$ \\
\hline 1 & 2 & 3 & 4 & 5 \\
\hline B1 & $\begin{array}{l}\text { Yeah maybe but I think you're } \\
\text { right I mean talking about } \\
\text { everybody in Europe in the } \\
\text { Middle Ages it was all horrible } \\
\text { there were a lot of brutality and } \\
\text { everything but I do think you } \\
\text { know I don't know I believe that } \\
\text { I believe that it gets passed } \\
\text { down you know and that it } \\
\text { hasn't faded yet or it's just } \\
\text { slowly fading and I think that's } \\
\text { why we have a lot of bitterness } \\
\text { and fear and guilt and that's } \\
\text { what's so toxic to find happiness }\end{array}$ & & & \\
\hline G1 & $\begin{array}{l}\text { but not so much the young } \\
\text { generation, it's more our parents } \\
\text { and grandparents of course but I } \\
\text { think the side is in general a } \\
\text { little more stiff more stiff }\end{array}$ & $\begin{array}{l}\text { negative judgement } \\
\text { of normality }\end{array}$ & & $\begin{array}{l}\text { OP Germans in } \\
\text { Germany }\end{array}$ \\
\hline G2 & $\begin{array}{l}\text { there are not to say that it's not } \\
\text { conservative here in some ways } \\
\text { it is }\end{array}$ & $\begin{array}{l}\text { negative } \\
\text { appreciation }\end{array}$ & & OP US \\
\hline G3 & $\begin{array}{l}\text { but in Germany I think if it } \\
\text { comes to living the way } \\
\text { Germans live together it's still } \\
\text { very conservative so uhm }\end{array}$ & $\begin{array}{l}\text { negative judgement } \\
\text { of normality }\end{array}$ & & $\begin{array}{l}\text { OP Germans in } \\
\text { Germany }\end{array}$ \\
\hline G4 & they're less casual about it & $\begin{array}{l}\text { negative judgement } \\
\text { of normality }\end{array}$ & & $\begin{array}{l}\text { OP Germans in } \\
\text { Germany }\end{array}$ \\
\hline G5 & $\begin{array}{l}\text { and so here it's just up to you } \\
\text { you know uhm people }\end{array}$ & $\begin{array}{l}\text { positive } \\
\text { appreciation }\end{array}$ & & OP US \\
\hline M1 & $\begin{array}{l}\text { America is much more right } \\
\text { wing than Germany is }\end{array}$ & $\begin{array}{l}\text { negative } \\
\text { appreciation }\end{array}$ & & OP US \\
\hline G6 & yes & & & \\
\hline M2 & $\begin{array}{l}\text { in general the bay area of course } \\
\text { is different }\end{array}$ & $\begin{array}{l}\text { positive } \\
\text { appreciation }\end{array}$ & & OP US Bay Area \\
\hline G7 & $\begin{array}{l}\text { Yeah like the Mid West right } \\
\text { uhm }\end{array}$ & $\begin{array}{l}\text { negative } \\
\text { appreciation }\end{array}$ & & OP US Mid West \\
\hline G8 & $\begin{array}{l}\text { well I didn't mean to go there } \\
\text { but just in general in terms of } \\
\text { like you know like in Germany } \\
\text { you still find families in they } \\
\text { have like Mittagessen }\end{array}$ & $\begin{array}{l}\text { negative judgement } \\
\text { of normality }\end{array}$ & & $\begin{array}{l}\text { OP Germans in } \\
\text { Germany }\end{array}$ \\
\hline G9 & $\begin{array}{l}\text { I mean it's still like you don't } \\
\text { come to their house you don't } \\
\text { disturb there's Mittagsruhe or } \\
\text { after a certain time you do not } \\
\text { call you don't find I mean }\end{array}$ & $\begin{array}{l}\text { negative judgement } \\
\text { of normality }\end{array}$ & & $\begin{array}{l}\text { OP Germans in } \\
\text { Germany }\end{array}$ \\
\hline
\end{tabular}




\begin{tabular}{|c|c|c|c|c|}
\hline & & Appraisal & $\begin{array}{l}\text { Positioning of the } \\
\text { speaker } \\
\text { ("narrating I/ } \\
\text { narrated I") }\end{array}$ & $\begin{array}{l}\text { Positioning of the } \\
\text { third party }\end{array}$ \\
\hline 1 & 2 & 3 & 4 & 5 \\
\hline M3 & $\begin{array}{l}\text { You do not call between } 8 \text { and } \\
8.15\end{array}$ & $\begin{array}{l}\text { negative judgement } \\
\text { of normality }\end{array}$ & & $\begin{array}{l}\text { OP Germans in } \\
\text { Germany }\end{array}$ \\
\hline G10 & Yeah so it's & & & \\
\hline A1 & Tagesschau! & & & \\
\hline G11 & $\begin{array}{l}\text { Yeah } \\
\text { (All laugh) }\end{array}$ & & & \\
\hline G12 & $\begin{array}{l}\text { or you know you know when } \\
\text { you have lunchtime and people } \\
\text { sometimes in Germany really } \\
\text { they ask the guest to leave it }\end{array}$ & $\begin{array}{l}\text { negative judgement } \\
\text { of normality }\end{array}$ & & $\begin{array}{l}\text { OP Germans in } \\
\text { Germany }\end{array}$ \\
\hline Int 1 & Yeah & & & \\
\hline G13 & $\begin{array}{l}\text { It's really true I mean I don't } \\
\text { wanna (?) on it but it's really } \\
\text { family time and uhm and has } \\
\text { changed of course }\end{array}$ & $\begin{array}{l}\text { positive } \\
\text { appreciation }\end{array}$ & & $\begin{array}{l}\text { OP life in } \\
\text { Germany }\end{array}$ \\
\hline G14 & $\begin{array}{l}\text { so I don't think you would find } \\
\text { that here }\end{array}$ & $\begin{array}{l}\text { negative judgement } \\
\text { of normality }\end{array}$ & & OP Germany \\
\hline B2 & $\begin{array}{l}\text { My parents do that too my mom } \\
\text { never would invite people over } \\
\text { for lunch for }\end{array}$ & $\begin{array}{l}\text { negative judgement } \\
\text { of normality }\end{array}$ & & $\begin{array}{l}\text { OP German } \\
\text { parent's behaviour }\end{array}$ \\
\hline G15 & ja & & & \\
\hline G16 & yeah & & & \\
\hline G17 & yeah & & & \\
\hline B3 & $\begin{array}{l}\text { Mittagessen she was really } \\
\text { meant go home (?) it's not }\end{array}$ & $\begin{array}{l}\text { negative judgement } \\
\text { of normality }\end{array}$ & & $\begin{array}{l}\text { OP German } \\
\text { parent's behaviour }\end{array}$ \\
\hline G18 & $\begin{array}{l}\text { (?) They are not trying to be } \\
\text { mean, }\end{array}$ & $\begin{array}{l}\text { positive judgement } \\
\text { of veracity }\end{array}$ & & $\begin{array}{l}\text { OP German } \\
\text { parent generation }\end{array}$ \\
\hline G19 & $\begin{array}{l}\text { it's just their culture it's just the } \\
\text { way they were brought up }\end{array}$ & $\begin{array}{l}\text { negative judgement } \\
\text { of capacity; } \\
\text { normality }\end{array}$ & & $\begin{array}{l}\text { OP German } \\
\text { parent generation }\end{array}$ \\
\hline
\end{tabular}

Table 3: Appraisal and positioning acts. $\mathrm{SP}=$ self-positioning; $\mathrm{OP}=$ other-positioning; italics = inscribed/invoked appraisal; bold $=$ propositions with code-switching

The episode occurs in an extended sequence in which the participants talk in response to the interviewer's question what made them leave Germany. The episode serves to evaluate German society and German cultural practices and present the participants in the interview encounter in literally another time and space. The third parties invoked for this purpose are Germans in Germany, the German parent generation, and the US.

The interviewees' other-positioning of Germans in Germany is connected with predominantly negative evaluations regarding the 'normality' of their behaviour. Normality seems to be assessed on the basis of a consensual American norm assumed to be known by all participants. The other-positioning of the US is primarily associated with positive evaluations. However, some other-positionings of Germans and the US mitigate to a certain degree an otherwise rather black-and-white-like contrastive evaluation of Germans and the US (e.g. "America is 
much more right-wing" (M1); "they are not trying to be mean" (G18); "it's really family time" (G13) also G2, G7, G19).

The code-switches into German occur in the context of negative evaluations of the 'normality' of German practices. Especially Mittagessen ('lunch') serves to orient the interview participants towards a specific characteristic of German culture, which is presented as iconic for the conservativism and stiffness characterizing life in Germany. ${ }^{3}$ The code-switches Mittagsruhe (period of rest around midday) and Tagesschau (prime time news broadcast) seem to be used as further evidence for the existence of these cultural characteristics. The expressions are used by three of the interviewees, which suggests that, in their view, at that moment of the interaction, the concepts evoked through the code-switches really characterize Germany and the contrast between Germany and the US. The second use of Mittagessen (B3) is a self-repair for "lunch" (B2). This shows that culture-specific connotations of Mittagessen are important for the speaker. It is the social event Mittagessen and not 'lunch' that is associated with particular types of behaviour that are posited as specifically German.

It is important to stress that, in this case, the culture-specific connotations are essentially group-specific connotations. The functionality of the code-switch is dependent on its power to signal contextual presuppositions, which, in turn, rest upon the assumption that all participants share a particular kind of knowledge about Germany. The connotations of the German expressions crucially drive on a specific perception of Germany by Germans living in the US. In another context, e. g. in a group of Germans in Germany, Mittagessen might not have any of these connotations at all.

The switches serve to create group solidarity and group cohesion through a process of collective remembering the home culture. Through the code-switches, the speakers associate the evaluation of German society and typical behaviour with concepts all other participants know and can relate to. The speakers assume that the participants' transportable identities of 'German immigrants in the US' provide a shared common ground of knowledge about both the US and Germany that provides the same denotational and connotational meanings for the codeswitched expressions. Early in the episode, participant G, who uses the code-switches Mittagessen and Mittagsruhe first, tries to describe and characterize differences between life in Germany and in the US in general terms (G1-5). This is met by a challenging objection by participant M (M1). G then re-traces his argument using the code-switches to trigger a process of collective remembering, which results in the collaborative construction of a consensual and unchallenged group opinion about the third party.

\section{$7 \quad$ Conclusion}

The analyses highlight the function of code-switching as a marker of evaluation, the role of evaluative code-switches in speakers' practices of self- and other-positioning in discourse, and the affordances of the sociolinguistic research interview as the communicative context which gives rise to the production of code-switches in the first place.

The analyses further show that often equivalent expressions in English are present in the interviewees' accounts, for example as translations and paraphrases and 'repairables' (Jefferson et al. 1977). The English meanings are present but apparently deemed insufficient for the purpose at hand. Through code-switching, the interviewees take advantage of the communicative effects of the switching between languages itself and the culture-specific connotations of the code-switched expressions. Again, these only become exploitable through the particular constellation of situational and transportable identities both manifest and latent in the individuals present in the interview encounters. The interviewee's code-switches are instances of explicit

\footnotetext{
${ }^{3}$ Cf. also Du Bois (2009).
} 
orientation towards these identities and it is against these identities that the absent third person gains particular markedness.

Code-switching into German puts contrastive focus on the third parties in the interviewees' accounts of their life experiences. The code-switched expressions are 'specific', i. e., for the interviewees, they appear to have highly distinctive indexical and iconic meaning in the context of comparing the home and the host culture. Some of the expressions are rich in culturespecific connotations outside the interview context (Man tut das nicht, Ausländers), while others (Mittagessen) seem to carry culture-specific connotations that are typical for the group in which they are used. On their own, the code-switches are not evaluative or unequivocally connected to positive or negative evaluations. ${ }^{4}$ They only gain distinctly positive and negative evaluative meaning through their co-occurrence with evaluations of the third parties they are associated with and the positioning of the interviewee in relation to the third parties. In addition, the code-switches emphasize whichever kind of evaluation is expressed by virtue of their signalling capacity, which indicates that specific contextual presuppositions are relevant in utterance interpretation.

The interviewees exploit the presence of multiple identities, the culture-specific connotations of the code-switched expressions and the signalling value of the code-switch itself for three interrelated purposes: First, characterizing third parties in relation to the culture and value systems associated with the language of the code-switch; secondly, presenting the third party to the L1 German interlocutors for acceptance and concurring and sympathetic evaluation; and thirdly, validating and authenticating their potentially contestable subjective evaluations on the basis of an assumed shared common ground. Accordingly, the language mix can be seen as a "performance feature" (Bamberg 1997) of the interviewees' account, which, in the particular situation in which the account is set $-i$. e. the research interview - helps to achieve the telling itself and their goal in telling. The code-switches 'lure' the interviewer into the interviewees' account to make evaluations of third parties and the interviewees' themselves more palpable and compelling.

\section{References}

Bamberg, Michael G.W. (1996): "Emotion talk(s). The role of perspective in the construction of emotions". In: Niemeier, Susanne/Dirven, René (eds.): The Language of Emotions. Amsterdam, John Benjamins: 209-225.

Bamberg, Michael G.W. (1997): "Positioning between structure and performance". Journal of Narrative and Life History 7 (1-4): 335-342.

Bamberg, Michael G.W. (ed.) (2000): "Narrative identity". Narrative Inquiry (special issue) 10 (1).

Bock, Zannie (2008): "Language has a heart: Linguistic markers of evaluation in selected TRC testimonies". Journal of Multicultural Discourses 3(3): 189-203.

Davies, Bronwyn/Rom Harré (1990): "Positioning. The discursive construction of selves". Journal of the Theory of Social Behaviour 20: 43-63.

DeFina, Anna/Perrino, Sabina (2011): "Introduction: Interviews vs. 'natural' contexts: A false dilemma". Language in Society 40: 1-11.

Du Bois, Inke (2007): Germans in the United States: Reinventing Cultural Identities in Discourse. Saarbrücken: VDM Publishers.

Du Bois, Inke (2009): "Structural constraints on intramorphological codeswitching and implications on cultural identities of German immigrants". In: Cornillie, Bert/Lambert, Bert/Swiggers, Pierre (eds.): Linguistic Identities, Language Shift and Language Policy in Europe. Leuven/Paris/Walpole, Peeters: 27-43.

\footnotetext{
${ }^{4}$ With the possible exception of "Ausländers"; see Section 6.2.
} 
Du Bois, Inke (2010a): Discursive Constructions of Immigrant Identity. A Sociolinguistic Trend Study on Long-Term American Immigrants. Frankfurt/New York: Peter Lang.

Du Bois, Inke (2010b): "Language attrition and code-switching as markers of intercultural identity of American immigrants". In: Anthonissen, Christine/van der Walt, Christa (eds.): Stellenbosch Papers in Linguistics (SPIL) PLUS 39: 1-16.

Gumperz, John J. (1982): Discourse Strategies. Cambridge: Cambridge University Press.

Jefferson, Gail/Schegloff, Emanuel A./Sacks, Harvey (1977): "The preference for self-correction in the organization of repair in conversation". Language 53(2): 362-382.

Labov, William (1972): Sociolinguistic Patterns. Philadelphia: University of Pennsylvania Press.

Lucius-Hoene, Gabriele/Deppermann, Arnulf (2002): Rekonstruktion narrativer Identität. Opladen: Leske und Budrich.

Lucius-Hoene, Gabriele/Deppermann, Arnulf (2004): "Narrative Identität und Positionierung". Gesprächsforschung - Online-Zeitschrift zur verbalen Interaktion 5: 166183.

Martin, James R./White, Peter R. R. (2005): The Language of Evaluation: Appraisal in English. Basingstoke: Palgrave Macmillan.

Myers-Scotton, Carol (1988): "Code-Switching and types of multilingual communities". In: Lowenberg, Peter H. (ed.): Language Spread and Language Policy. Washington DC, Georgetown University Press: 61-82.

Myers-Scotton, Carol (1993): Duelling Languages. Clarendon Press: Oxford.

Myers-Scotton, Carol (2006): Multiple Voices: An Introduction to Bilingualism. Malden, Mass.: Blackwell.

Ochs, Elinor and Schieffelin, Bambi B. (1989): "Language has a heart". Text 9(1): 7-25.

Thompson, Geoffrey/Hunston, Susan (1999): "Evaluation: An introduction". In: Hunston, Susan/Thompson, Geoffrey (eds.): Evaluation in Text. Authorial Stance and the Construction of Discourse. Oxford, Oxford University Press: 1-17.

White, Peter R. R. (2005): An Introductory Tour through Appraisal Theory. Available at: http://www.grammatics.com/appraisal/AppraisalOutline/Framed/Frame.htm, accessed January 18, 2011.

Zimmerman, Don H. (1998): "Identity, context and interaction". In: Antaki, Charles/Widdicombe, Sue (eds.): Identities in Talk. London, Sage: 87-106.

\section{Transcription symbols}

(.) micro pause

CAPS stressed syllables

" " quotation intonation

? rising intonation

! exclamative

(?) unclear

[ onset of overlap

$=\quad$ cut-off 